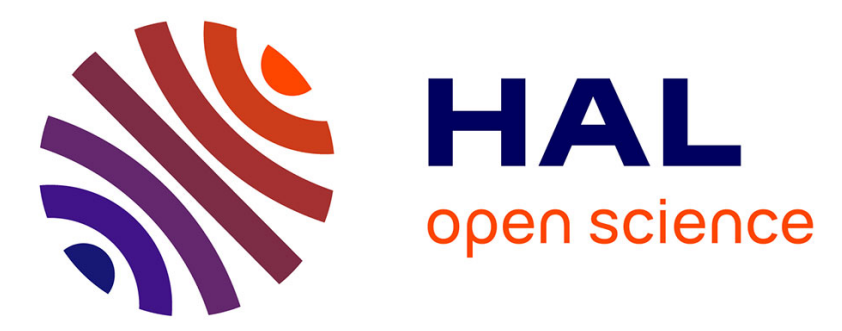

\title{
Hormonal changes during meiotic maturation and ovulation in the brook trout (Salvelinus fontinalis)
}

Frederick W. Goetz, Alexis Fostier, Bernard Breton, Bernard Jalabert

\section{To cite this version:}

Frederick W. Goetz, Alexis Fostier, Bernard Breton, Bernard Jalabert. Hormonal changes during meiotic maturation and ovulation in the brook trout (Salvelinus fontinalis). Fish Physiology and Biochemistry, 1987, 3 (4), pp.203-211. 10.1007/BF02180281 . hal-02728152

\section{HAL Id: hal-02728152 \\ https://hal.inrae.fr/hal-02728152}

Submitted on 2 Jun 2020

HAL is a multi-disciplinary open access archive for the deposit and dissemination of scientific research documents, whether they are published or not. The documents may come from teaching and research institutions in France or abroad, or from public or private research centers.
L'archive ouverte pluridisciplinaire HAL, est destinée au dépôt et à la diffusion de documents scientifiques de niveau recherche, publiés ou non, émanant des établissements d'enseignement et de recherche français ou étrangers, des laboratoires publics ou privés.

\section{다(1)(2)}

Distributed under a Creative Commons Attribution - ShareAlikel 4.0 International 


\title{
Hormonal changes during meiotic maturation and ovulation in the brook trout (Salvelinus fontinalis)
}

\author{
Frederick W. Goetz ${ }^{1}$, Alexis Y. Fostier ${ }^{2}$, Bernard Breton ${ }^{2}$, Bernard Jalabert ${ }^{2}$ \\ ${ }^{1}$ University of Notre Dame Department of Biological Sciences Notre Dame, Indiana 46556, USA \\ ${ }^{2}$ Laboratoire de Physiologie des Poissons Institut National Recherche Agronomique Campus de Beaulieu \\ Rennes cedex, France
}

Keywords: estradiol-17 $\beta, 17 \alpha, 20 \beta$-dihydroxy-4-pregnen-3-one, gonadotropin, vitellogenesis, ovarian maturation

\begin{abstract}
The plasma levels of estradiol-17 $\beta$ (E2), 17 $\alpha, 20 \beta$-dihydroxy-4-pregnen-3-one (17,20-P) and gonadotropin $(\mathrm{GTH})$ were measured in brook trout (Salvelinus fontinalis) during the period from the end of vitellogenesis to postovulation. Blood samples were taken according to specific stages of maturation, including germinal vesicle breakdown (GVBD) and ovulation. E2 levels were quite high $(\sim 45 \mathrm{ng} / \mathrm{ml})$ at the end of vitellogenesis (and prior to GVBD) and dropped precipitously by GVBD $(\sim 2 \mathrm{ng} / \mathrm{ml})$. They remained low through ovulation and postovulation. 17,20-P levels were low prior to GVBD $(\sim 0.7 \mathrm{ng} / \mathrm{ml})$ and increased dramatically at GVBD $(-148 \mathrm{ng} / \mathrm{ml})$. The levels of 17,20-P remained high at ovulation $(\sim 142 \mathrm{ng} / \mathrm{ml})$ and then dropped significantly within $24 \mathrm{~h}$ to approximately half of the ovulatory values. They decreased even further by 7 days postovulation. GTH levels rose gradually through GVBD and ovulation from a postvitellogenic level of approximately $3 \mathrm{ng} / \mathrm{ml}$ to a 7 day postovulatory value of approximately $10 \mathrm{ng} / \mathrm{ml}$. The overall results; 1) decrease in estradiol prior to GVBD, 2) increase in 17,20-P at GVBD and 3) gradual GTH rise through GVBD and ovulation, are similar to those reported for other salmonids.
\end{abstract}

\section{Introduction}

Over the last five years there have been many papers describing the changes in circulating steroids and gonadotropins in fish during the period from vitellogenesis until ovulation. Most of these investigations have been conducted on salmonids and major trends in the results of these studies appear reasonably similar. Circulating estradiol (vitellogenic hormone) is relatively high prior to final oocyte maturation and drops precipitously prior to germinal vesicle breakdown (GVBD). On the other hand, the levels of $17 \alpha, 20 \beta$-dihydroxy-4-pregnen-3-one (17,20-P: maturational hormone) are low prior to final maturation and begin to increase just prior to GVBD. They generally increase dramatically during GVBD and may increase even further following ovulation. Gonadotropin levels increase gradually prior to ovulation and generally continue to increase postovulation. Although this general pattern of hormonal changes is very similar from one salmonid species to another, there are some subtle differences. The most evident of these is in the absolute level of steroids and gonadotropins measured. For example, reported peak levels of $17,20-\mathrm{P}$ have varied from approximately $60 \mathrm{ng} / \mathrm{ml}$ in amago salmon (Young et al. 1983) to between 300 and $400 \mathrm{ng} / \mathrm{ml}$ in rainbow trout (Fostier'et al. 1986; Scott et al. 1983; Springate et al. 1984). Also, the rate and duration of steroid changes have varied between species.

For several years, we have been investigating the 
hormonal control of oocyte final maturation and ovulation in the brook trout (Salvelinus fontinalis) using an in vitro incubation system. One of the objectives of the present study was to determine the changes in circulating steroid and gonadotropin levels prior to and during final maturation so that they could be compared to results from other salmonid species and to our past in vitro results. Compared to other salmonids, there have only been a few reports concerning hormonal changes in members of the genus Salvelinus (Kagawa et al. 1981; Tam et al.1986). Since this species is now being used in the assay of acidic environmental conditions (Tam and Payson 1986), it is important to describe the basic biology of this species; particularly reproduction.

A second important objective of this study was to critically observe the hormone levels, especially 17,20-P, at the time of GVBD and ovulation. Although a large number of papers have reported on hormonal changes during the reproductive season, only a few of these have critically correlated the changes with specific maturational stages (e.g. germinal vesicle position, GVBD and ovulation). In many past studies, blood samples have been taken on a chronological basis which frequently will not allow for strict correlations between hormone levels and specific maturational stages. In the present study, samples were obtained according to the attainment of specific stages such as GVBD or ovulation. We were particularly interested to see if there was a consistent change in 17,20-P levels between GVBD and ovulation. Past investigations in this laboratory have studied the possible interactions of prostaglandins in brook trout ovulation (Goetz et al. 1982; Cetta and Goetz 1982; Goetz and Cetta 1983) and future investigations are directed at studying the possible hormonal regulation of prostaglandin synthesis by steroids and gonadotropins. Thus, it would be helpful to know more about the basic hormonal events that occur in this species during final maturation and ovulation.

\section{Materials and methods}

\section{Animals}

Female brook trout $(300-400 \mathrm{~g})$ were purchased during the reproductive season from private fish hatcheries in northern Wisconsin. They were held under natural photoperiods in tanks supplied with continuously flowing wellwater at $12.5^{\circ} \mathrm{C}$. Oocyte samples were obtained from fish by gentle pressure applied to the abdomen as previously described (Cetta and Goetz 1982). These oocytes were treated in a fixative (Goetz and Bergman 1978) to determine germinal vesicle position within the oocyte. At the time of the first blood sample (October 4, 1984), fish contained ovaries in which the germinal vesicle was approximately $4 / 5$ the distance from the center to the egg membrane. A total of nine fish were used in the investigation and they were serially blood sampled, relative to maturational stage, as described below.

\section{Blood sampling}

Initial blood samples were taken from fish prior to any extensive cytoplasmic clearing and before the germinal vesicle had reached the egg membrane. Following this, the ovaries of these fish were periodically monitored to determine the time of GVBD, and a second blood sample was taken at this time. Obtaining fish exactly at the time of GVBD is extremely difficult. As a result, of the 9 fish in the experiment only 6 were sampled at exactly this period. When it was determined that a fish had undergone GVBD, it was examined at least every $6 \mathrm{~h}$ to determine when ovulation occurred. This was accomplished by applying slight pressure to the abdomen to observe the extrusion of ovulated eggs. A blood sample was taken when eggs could be easily extruded from the ovipore and the abdomen had softened. Although this ovulatory criterion may be considered somewhat arbitrary, we feel that, as a result of past experiments involving similar sampling, in which fish were actually killed at each period (Cetta and Goetz 1982), this time represents a point at which fish are just fully 
ovulated or nearly so. This would not be considered the beginning of ovulation which is extremely difficult to ascertain in salmonids without actually killing the fish. Serial blood samples were also taken $24 \mathrm{~h}$ and 7 days postovulation. In all postovulatory samples, fish still contained ovulated eggs in the body cavity. Very little spontaneous oviposition could be observed up to 7 days postovulation.

At each sampling time, a $1.0 \mathrm{ml}$ sample of blood was removed from the caudal vasculature using a $1.0 \mathrm{ml}$ syringe fitted with a 23 gauge needle. Syringes were pre-rinsed in a $1,000 \mathrm{IU} / \mathrm{ml}$ heparin solution. Blood was centrifuged at $1,500 \mathrm{~g}$ for 20 minutes at $4^{\circ} \mathrm{C}$ after which the plasma was removed and stored at $-20^{\circ} \mathrm{C}$ until assayed.

\section{Hormone assay}

For steroid assays, $400 \mu \mathrm{l}$ of plasma was extracted twice with $2.0 \mathrm{ml}$ of a mixture of ethyl acetate:cyclohexane (1:1) and the extracts separated on LH-20 according to the methods described by Fostier and Jalabert (1986). Radioimmunoassays (RIA) of 17,20-P and estradiol-17 $\beta$ were performed as described by Fostier et al. (1981) and Jalabert and Fostier (1984). Cross-reactivities of various steroids with the antisera used in the RIAs have been described (Fostier and Jalabert 1986; Jalabert and Fostier 1984).

Gonadotropin was measured by RIA using an antibody directed against salmon gonadotropin. The assay and its characteristics have been described previously (Breton et al. 1978).

\section{Analysis and statistics}

RIA data was analyzed using a logit-log transformation and all potency estimates for steroids were corrected for the procedural loss of material during extraction and separation. Potencies given in the text and figures are expressed as the mean \pm SEM. Potency estimates at various stages were analyzed using a one-way ANOVA followed by Tukey's multiple comparison test.

\section{Results}

\section{GVBD and ovulation}

The first blood sample was taken on Oct. 4 (1984) at which time all fish contained oocytes with subperipheral germinal vesicles. The first fish to undergo GVBD did so on Oct. 7 while the last underwent GVBD on Oct. 28. The time from GVBD to ovulation varied between 1 and 2 days. For 6 fish, the exact time of GVBD could be determined (i.e. we were able to follow the germinal vesicle as it dispersed). For 5 of these fish we were reasonably sure that an ovulatory sample was taken within $6 \mathrm{~h}$ of the time of ovulation. For an additional 3 fish we were not able to determine the exact time of GVBD but were able to determine that they had undergone GVBD but had not yet ovulated. These fish were followed at $6 \mathrm{~h}$ intervals and we were reasonably certain that an ovulatory blood sample was taken from them within $6 \mathrm{~h}$ of ovulation. Hence, the sample size of 8 at ovulation and at $24 \mathrm{~h}$ postovulation (Figs. $1-3$ ). One of the 8 fish died between the $24 \mathrm{~h}$ postovulatory sample and the 7 day postovulatory sample, hence the sample size of 7 for the last sample.

\section{Estradiol-173}

Circulating estradiol levels were high $(45.1 \pm 5.8$ (SEM) $\mathrm{ng} / \mathrm{ml}$ ) in fish containing oocytes with intact, subperipheral germinal vesicles (Fig. 1). At the time of GVBD the levels had dropped to $2.3 \pm 0.5$ $\mathrm{ng} / \mathrm{ml}$ and remained at approximately this level through 7 days postovulation. Pre-GVBD levels were significantly $(\mathrm{P}<0.05)$ higher than the mean levels at all other stages, but no other significant differences were observed.

\section{$17 \alpha, 20 \beta$-Dihydroxy-4-pregnen-3-one}

Females sampled prior to GVBD had very low circulating 17,20-P levels $(0.7 \pm 0.1 \mathrm{ng} / \mathrm{ml}$-Fig. 2$)$. At GVBD the levels had increased significantly ( $\mathrm{P}<$ 0.05 ) to a mean of $147.8 \pm 22.9 \mathrm{ng} / \mathrm{ml}$ and at ovu- 


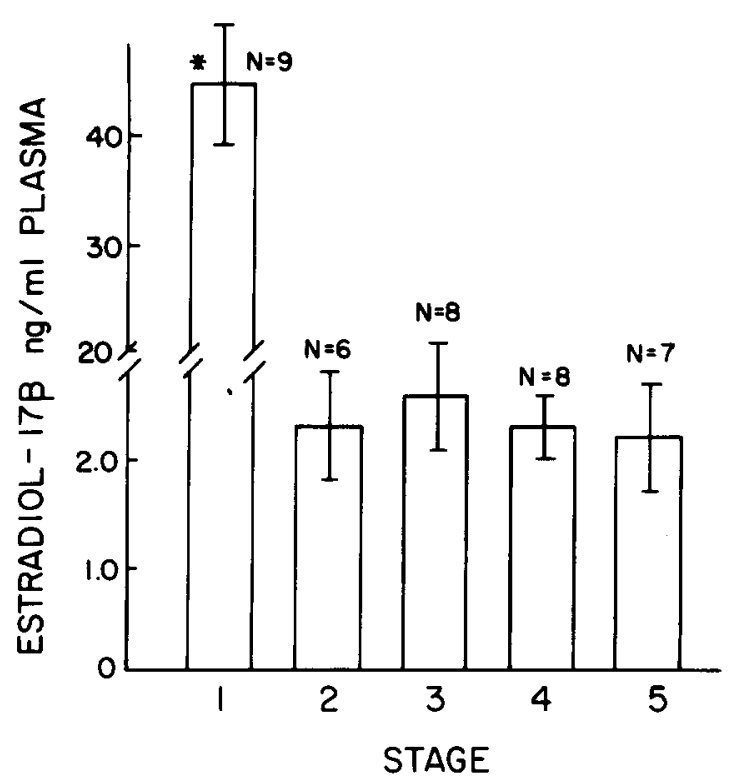

Fig. 1. Circulating estradiol- $17 \beta$ levels in brook trout at different stages of maturation and ovulation. Stage $1=$ prematurational; $2=\mathrm{GVBD} ; 3=$ ovulation; $4=24 \mathrm{~h}$ postovulation; $5=7$ days postovulation. All values are means $\pm \mathrm{SEM}$ for $\mathrm{N}$ fish. ${ }^{*}$ indicates significant difference from all other means at $\mathbf{P}<0.05$.

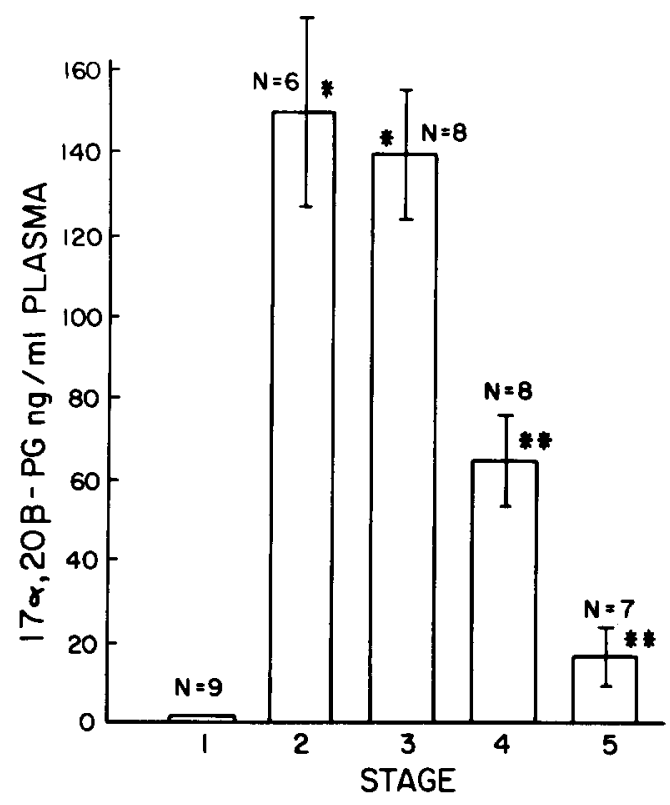

Fig. 2. Circulating 17,20-P levels in brook trout at different stages of maturation and ovulation. Stages as in Fig. 1. All values are means \pm SEM for $\mathrm{N}$ fish. Bars with similar * designation are not significantly different. All other comparisons significantly different at $\mathrm{P}<0.05$.

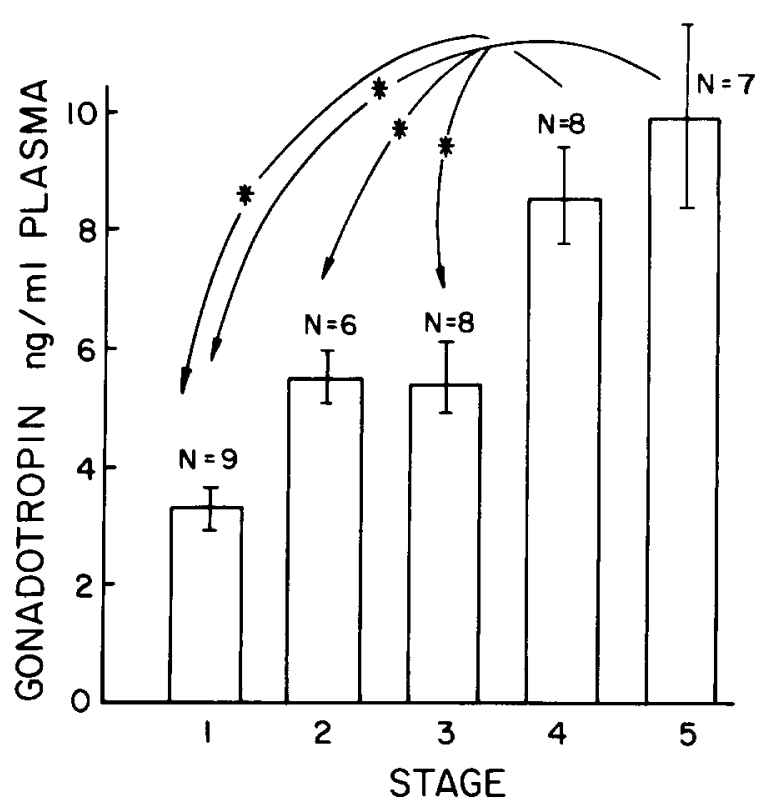

Fig. 3. Circulating gonadotropin levels in brook trout at different stages of maturation and ovulation. Stages as in Fig. 1. All values are means $\pm \mathrm{SEM}$ for $\mathrm{N}$ fish. * indicate significant differences at $\mathbf{P}<0.05$.

Table 1. 17,20-P levels in brook trout females serially sampled at GVBD and within $6 \mathrm{~h}$ of ovulation

\begin{tabular}{lrl}
\hline & \multicolumn{2}{c}{$17,20-\mathrm{P}(\mathrm{ng} / \mathrm{ml})$} \\
\cline { 2 - 3 } Fish & GVBD & Ovulation \\
\hline 1 & 92.5 & 217.5 \\
2 & 124.1 & 149.3 \\
3 & 202.0 & 150.5 \\
4 & 85.1 & 111.4 \\
5 & 218.7 & 97.9 \\
\hline
\end{tabular}

lation the levels remained at approximately this level $(142.0 \pm 15.7 \mathrm{ng} / \mathrm{ml})$. Of five fish in which a blood sample had been obtained exactly at GVBD and within $6 \mathrm{~h}$ of ovulation, the 17,20-P levels rose in 3 between GVBD and ovulation, and dropped in 2 of the fish (Table 1).

The levels of 17,20-P measured $24 \mathrm{~h}$ postovulation $(65.2 \pm 11.7 \mathrm{ng} / \mathrm{ml})$ were significantly $(\mathrm{P}<$ 0.05 ) lower than those measured at GVBD or ovulation but were still significantly $(P<0.05)$ higher than pre-maturational levels. By seven days postovulation, $17,20-\mathrm{P}$ levels $(16.5 \pm 8.9 \mathrm{ng} / \mathrm{ml})$ 
Table 2. Peak values of circulating $17,20-\mathrm{P}$ in salmonids during natural reproduction

\begin{tabular}{|c|c|c|c|}
\hline Species & $\begin{array}{l}17,20-\mathrm{PG} \\
(\mathrm{ng} / \mathrm{ml})\end{array}$ & Stage & Reference \\
\hline \multirow[t]{4}{*}{ Rainbow trout } & $320(X)$ & GVBD & Fostier et al. (1986) \\
\hline & $300-400$ & $\begin{array}{l}4 \text { days prior to } \\
\text { ovulation }\end{array}$ & Scott et al. (1983) \\
\hline & $400(X)$ & ovulation & Springate et al. (1984) \\
\hline & $113(X)$ & postovulation & Liley et al. (1986) \\
\hline Brook Trout & $148 / 142$ & GVBD/ovulation & present paper \\
\hline Chum Salmon & $332(\mathrm{X})$ & spawning population* & Ueda et al. (1984) \\
\hline \multirow[t]{2}{*}{ Coho Salmon } & 270 & $\begin{array}{l}4 \text { days prior to } \\
\text { ovulation }\end{array}$ & Van der Kraak et al. (1984) \\
\hline & $70-80$ & GVBD & Fitzpatrick et al. (1986) \\
\hline \multirow[t]{2}{*}{ Atlantic Salmon } & $120-280$ & ovulation & Wright and Hunt (1982) \\
\hline & $68(X)$ & $\begin{array}{l}\text { GVBD but prior } \\
\text { to ovulation }\end{array}$ & So et al. (1985) \\
\hline Amago Salmon & $50-70$ & GVBD/ovulation & Young et al. (1983) \\
\hline Sockeye Salmon & $74(\mathrm{X})$ & GVBD-presumed & Truscott et al. (1986) \\
\hline Masu Salmon & $30-70$ & $\begin{array}{c}2-4 \text { days prior to } \\
\text { ovulation }\end{array}$ & Yamauchi et al. (1984) \\
\hline
\end{tabular}

* sample contained ovulated and nonovulated females; $(\mathrm{X})=$ mean value.

were not significantly different from prematurational ones, however at this time the levels were extremely variable ranging from a high of $51.9 \mathrm{ng} / \mathrm{ml}$ to a low of $0.7 \mathrm{ng} / \mathrm{ml}$.

\section{Gonadotropin}

Gonadotropin (GTH) levels rose gradually from a pre-GVBD level of $3.3 \pm 0.4 \mathrm{ng} / \mathrm{ml}$ to a postovulatory ( 7 days) level of $9.9 \pm 1.6 \mathrm{ng} / \mathrm{ml}$ (Fig. 3). GTH levels measured at 7 days postovulation were significantly $(\mathrm{P}<0.05)$ higher than those measured prior to and during GVBD and ovulation. They were not significantly different from the levels measured $24 \mathrm{~h}$ postovulation $(8.5 \pm 0.9 \mathrm{ng} / \mathrm{ml})$. In addition, although the mean GTH levels at GVBD $(5.5 \pm 0.5 \mathrm{ng} / \mathrm{ml})$ and ovulation $(5.4 \pm 0.6 \mathrm{ng} / \mathrm{ml})$ were higher than those prior to GVBD, this difference was not significant.

\section{Discussion}

Levels of circulating steroids and gonadotropins during meiotic maturation and ovulation have been reported in a number of species in the Salmonidae. A summary of some of these results, pertinent to this discussion, are given in Tables 2 and 3. From the results given for $17,20-\mathrm{P}$ (Table 2), it appears that the absolute values of $17,20-P$ measured at GVBD or ovulation are greatest in rainbow trout in which levels are generally between 300 and 400 $\mathrm{ng} / \mathrm{ml}$ and much lower in several other species including amago salmon $(\sim 60 \mathrm{ng} / \mathrm{ml})$, masu salmon $(30-70 \mathrm{ng} / \mathrm{ml})$ and sockeye salmon $(74 \mathrm{ng} / \mathrm{ml})$. Thus, at levels of approximately $145 \mathrm{ng} / \mathrm{ml}$, brook trout appear to be intermediate between these species. The absolute level of steroid measured may be a result of the degree of domestication of the trout stock (Liley et al. 1986). Liley et al. (1986) observed that the maximum level of $17,20-\mathrm{P}$ measured in wild rainbow trout females was approximately 113 $\mathrm{ng} / \mathrm{ml}$ just following ovulation. This is considerably lower than that reported for domestic rainbow stocks (see Table 2). However, the wild trout were able to spawn which is not usually the case in studies on domestic rainbow trout. Social stimuli may also have an effect on the absolute level of hormones (Liley et al. 1986). In our study on brook trout, females were held together but isolated from males. In addition, the tanks used to hold females 
Table 3. Circulating levels of estradiol $-17 \beta$ at two stages of maturation in various species of salmonids

\begin{tabular}{|c|c|c|c|}
\hline \multirow[t]{2}{*}{ Species } & \multicolumn{2}{|c|}{$\begin{array}{l}\text { Estradiol } \\
(\mathrm{ng} / \mathrm{ml})\end{array}$} & \multirow[t]{2}{*}{ Reference } \\
\hline & Premat.* & $\mathrm{OV}$ or $\mathrm{POV}^{* *}$ & \\
\hline \multirow[t]{5}{*}{ Rainbow trout } & $\sim 20$ & $\sim 2$ & Fostier et al. (1986) \\
\hline & -18 & -2 & Scott et al. (1983) \\
\hline & $\sim 60$ & $30-2.8$ (spawning) & $\begin{array}{l}\text { van Bohemen and Lambert } \\
\text { (1981) }\end{array}$ \\
\hline & $\sim 50$ & $\sim 2$ & Scott and Sumpter (1983) \\
\hline & -48 & $\sim 2$ & Scott et al. (1982) \\
\hline Brown Trout & $\sim 7$ & $\sim 2$ & Breton et al. (1983) \\
\hline \multirow[t]{2}{*}{ Brook Trout } & -45 & -2 & present paper \\
\hline & $\sim 40$ & $\sim 5$ & Tam et al. (1986) \\
\hline \multirow[t]{3}{*}{ Coho Salmon } & $\sim 16$ & $1-2$ & van der Kraak et al. (1984) \\
\hline & $3-6$ & $2-3$ & Sower and Schreck (1982) \\
\hline & $13-18$ & $\sim 3$ & Fitzpatrick et al. (1986) \\
\hline Chum Salmon & $\sim 13$ & $\sim 5^{* * *}$ & Ueda et al. (1984) \\
\hline Atlantic Salmon & 34 & 0.9 & Stuart-Kregor (1981) \\
\hline Sockeye Salmon & -21 & $\sim 1$ & Truscott et al. (1986) \\
\hline Masu Salmon & $4-25$ & -1 & Yamauchi et al. (1984) \\
\hline White-spotted Char & -13 & -2 & Kagawa et al. (1981) \\
\hline
\end{tabular}

* time period varied from several days to one month prior to final maturation

** $\mathrm{OV}=$ ovulation and $\mathrm{POV}=$ postovulation

*** sample contained ovulated and nonovulated females

did not contain any gravel substrate and the females did not spontaneously release eggs.

The observation that $17,20-P$ levels were significantly elevated in brook trout at GVBD further supports a role for this steroid in the induction of meiotic maturation in this species. Past studies on this species have demonstrated that $17,20-\mathrm{P}$ is the most potent maturational steroid when tested in vitro (Duffey and Goetz 1980), and its synthesis by brook trout ovarian tissue has been tentatively demonstrated (Theofan and Goetz 1983). The results presented here also clearly demonstrate that in brook trout 17,20-P levels are elevated at GVBD and ovulation and that there is not a consistent increase or decrease in the circulating levels of this progestagen between these two periods. In coho salmon there was also no consistent change in the level of 17,20-P from GVBD to ovulation (Fitzpatrick et al. 1986), while in Atlantic salmon, Truscott et al. (1985) suggested that there was a slight decrease from the time just following GVBD until ovulation, though it is doubtful that this was sta- tistically significant. Regardless, in all investigations that have been reported so far, it cannot be precisely determined how long, following GVBD, that an ovulatory sample was taken. In several cases (Fostier et al. 1981; Fitzpatrick et al. 1986) serial samples were taken from fish at two or three day intervals and, therefore, 48-72 h may have elapsed between GVBD and ovulation. In other investigations the sampling periods were even wider apart or sampling was not done serially, making it impossible to determine how long, before the ovulatory sample, that the fish had undergone GVBD. Although we cannot say that our ovulatory sample was taken during the time of ovulation, because of our sampling regime it is possible to state that it was taken within $6 \mathrm{~h}$ of ovulation and this appears to be much closer to the time of GVBD than in any other investigation yet reported. Of course, the circulating levels may not accurately reflect synthetic changes that are occurring in the follicle, and these may be important in the stimulation of ovulation. Another interesting observation was that in brook 
trout, 17,20-P levels quickly dropped following ovulation in fish that still retained ovulated eggs in the body cavity. In rainbow trout, the levels of 17,20-P also drop following ovulation (Fostier et al. 1981) but since they are at least twice as high at ovulation as in brook trout it appears to take a longer time for them to decrease.

As Table 3 indicates, estradiol levels are relatively high prior to GVBD in all salmonids while at the time of ovulation they are generally low; 1-2 $\mathrm{ng} / \mathrm{ml}$. It has been suggested that the fall in estradiol is a consequence of a shift in the steroidogenic pathway prior to GVBD (Fostier and Jalabert 1986) and physiologically the decrease may be indirectly involved in the control of oocyte final maturation (Jalabert and Fostier 1984a,b). There appears to be quite a range of prematurational values for estradiol levels, though this may be related more to the exact time at which the sample was taken rather than a species difference in absolute concentrations. In brook trout the estradiol levels are very high, even shortly before GVBD. For example, in several fish that underwent GVBD within 9 days following the first blood sample, the mean was $\mathbf{3 7 . 7}$ $\mathrm{ng} / \mathrm{ml}$. In contrast, from the literature it appears that estradiol levels in rainbow trout at a similar period are lower; in the range of $10-20 \mathrm{ng} / \mathrm{ml}$ (Fostier et al. 1986).

The seasonal changes in estrogen levels in brook trout have recently been reported (Tam et al. 1986). Although these levels cannot be strictly related to the stages reported here since the sampling was not done on a stage basis, it does appear that near the end of vitellogenesis the levels reach a maximum of approximately $40 \mathrm{ng} / \mathrm{ml}$ (Tam et al. 1986). This value is nearly the same as the one we obtained for fish just prior to GVBD; presumably at a similar stage. In addition, our post-GVBD value of approximately $2.0 \mathrm{ng} / \mathrm{ml}$, is also similar to those reported for postovulatory brook trout (Tam et al. 1986). From the data presented here it would be assumed that in brook trout the estradiol levels remain high until just prior to GVBD; inferring that the drop is closely tied to final maturation. However, Tam and coauthors (1986) reported that, of brook trout obtained from two hatcheries, there was a decrease in estrogen in brook trout obtained from one of the hatcheries even though none of them had ovulated. Although it was not explicitly stated, it could be inferred from their figures that the decrease in this case was from approximately 40 $\mathrm{ng} / \mathrm{ml}$ to $25 \mathrm{ng} / \mathrm{ml}$. It could be that these fish were undergoing GVBD at just about the time that blood sampling was conducted and this was the reason for the decrease.

In the present study, gonadotropin levels increased gradually during GVBD and ovulation and reached peak values at seven days postovulation. This has also been observed in several other salmonids (Crim et al. 1975; Fostier et al. 1981; Scott et al. 1983). It should be pointed out that even though levels were greatest at 7 days postovulation, they were also quite variable at this time, ranging from a high of $15.1 \mathrm{ng} / \mathrm{ml}$ to a low of $4.0 \mathrm{ng} / \mathrm{ml}$. In rainbow trout, GTH levels continue to increase following ovulation and can reach values as high as $100 \mathrm{ng} / \mathrm{ml}$ in fish still holding eggs in the body cavity and $50 \mathrm{ng} / \mathrm{ml}$ in fish spent immediately following ovulation (Jalabert and Breton 1980). Truscott et al. (1986) also reported GTH values of $90 \mathrm{ng} / \mathrm{ml}$ in post-spawned sockeye salmon. It is possible that higher values would have been observed in some brook trout females if sampling was continued. In addition, in rainbow trout, GTH levels decline somewhat following ovulation and then increase even further following this decline (Fostier et al. 1981). Of the 7 females sampled at 7 days postovulation, GTH levels had begun to decline in 3 and this might indicate that sampling may have occured in a transient postovulatory trough. In comparison to rainbow trout, the absolute values of GTH measured were lower in brook trout but this may have been the result of using a RIA based on salmon GTH. Using a RIA based on salmon gonadotropin, Crim et al. (1975) also reported an increase in plasma GTH in brook trout through the time of ovulation. Although it is difficult to exactly compare the two studies, it appears that the GTH levels measured were slightly higher in the earlier study by Crim et al. (1975) compared to the present one. 


\section{Acknowledgements}

The authors gratefully acknowledge the technical assistance of Odile Marcuzzi and Elisabeth Sambroni.

This material is based upon work partially supported by a NATO Grant for International Collaboration (\#85/0147) to FWG and AYF.

\section{References cited}

Breton, B., Prunet, P. and Reinaud, P. 1978. Sexual differences in salmon gonadotropin. Ann. Biol. anim. Bioch. Biophys. 18: 759-765.

Breton, B., Fostier, A., Zohar, Y., Lebail, P.Y. and Billard, R. 1983. Gonadotropine glycoproteique maturante et oestradiol-17 $\beta$ pendant le cycle reproducteur chez la truite fario (Salmo trutta) femelle. Gen. Comp. Endocrinol. 49: 220231.

Cetta, F., and Goetz, F.W. 1982. Ovarian and plasma prostaglandin $\mathrm{E}$ and $\mathrm{F}$ levels in brook trout (Salvelinus fontinalis) during ovulation. Biol. Reprod. 27: 1216-1221.

Crim, L.W., Watts, E.G. and Evans, D.M. 1975. The plasma gonadotropin profile during sexual maturation in a variety of salmonid fishes. Gen. Comp. Endocrinol. 27: 62-70.

Duffey, R.J. and Goetz, F.W. 1980. The in vitro effects of $17 \alpha-$ hydroxy-20ß-dihydroprogesterone on germinal vesicle breakdown in brook trout (Salvelinus fontinalis) oocytes. Gen. Comp. Endocrinol. 41: 563-565.

Fitzpatrick, M.S., Van Der Kraak, G. and Shreck, C.B. 1986. Profiles of sex steroids and gonadotropin in coho salmon, Oncorhynchus kisutch, during final maturation. Gen. Comp. Endocrinol. 62: 437-451.

Fostier, A., Jalabert, B., Campbell, C., Terqui, M. and Breton, B. 1981. Cinetique de liberation in vitro de $17 \alpha$-hydroxy20ß-dihydroprogesterone par des follicles de truite arc-enciel, Salmo gairdneri. C.R. Acad. Sci. Paris 292: 777-780.

Fostier, A., Breton, B., Jalabert, B. and Marcuzzi, O. 1981. Evolution des niveaux plasmatiques de la gonadotropine glycoproteique et de la $17 \alpha$ hydroxy-20 $\beta$ dihydroprogesterone au cours de la maturation et de l'ovulation chez la truite arcen-ciel, Salmo gairdneri. C.R. Acad. Sci. Paris 293: 817-820.

Fostier, A., and Jalabert, B. 1986. Steroidogenesis in rainbow trout (Salmo gairdneri) at various preovulatory stages: Changes in plasma hormone levels and in vivo and in vitro responses of the ovary to salmon gonadotropin. Fish. Physiol. Biochem. 2: 87-99.

Goetz, F.W. and Bergman, H.L. 1978. The effects of steroids on final maturation and ovulation of oocytes from brook trout (Salvelinus fontinalis) and yellow perch (Perca flavescens). Biol. Reprod. 18: 293-298.

Goetz, F.W. and Cetta, F. 1983. Ovarian and plasma PGE and PGF levels in naturally ovulating brook trout (Salvelinus fon- tinalis) and the effects of indomethcin on prostaglandin levels. Prostaglandins 26: 387-395.

Goetz, F.W., Smith, D.C., and Krickl, S.P. 1982. The effects of prostaglandins, phosphodiesterase inhibitors, and cyclic AMP on ovulation of brook trout (Salvelinus fontinalis) oocytes. Gen. Comp. Endocrinol. 48: 154-160.

Jalabert, B. and Breton, B. 1980. Evolution de la gonadotropine plasmatique $\mathrm{t}-\mathrm{GtH}$ apres l'ovulation chez la truite arc-en-ciel (Salmo gairdneri R.) et influence de la retention des ovules. C.R. Acad. Sci. Paris 290: 799-801.

Jalabert, B. and Fostier, A. 1984a. The follicular sensitivity in vitro to maturation inducing hormones in rainbow trout, Salmo gairdneri role of estradiol-17 $\beta$. Aquaculture 43: 1-11.

Jalabert, B. and Fostier, A. 1984b. The modulatory effect in vitro of oestradiol- $17 \beta$, testosterone or cortisol on the output

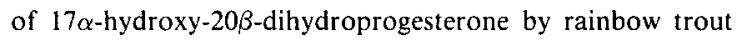
(Salmo gairdneri) ovarian follicles stimulated by the maturational gonadotropin S-GTH. Reprod. Nutr. Develop. 24: $127-136$.

Kagawa, H., Takano, K. and Nagahama, Y. 1984. Correlation of plasma estradiol-17 $\beta$ and progesterone levels with ultrastructure and histochemistry of ovarian follicles in the whitespotted char, Salvelinus leucomaenis. Cell Tiss. Res. 219: 315-329.

Liley, N.R., Fostier, A., Breton, B. and Tan, E.S.P. 1986. Endocrine changes associated with spawning behavior and social stimuli in a wild population of rainbow trout (Salmo gairdneri) II. Females. Gen. Comp. Endocrinol. 62: 157167.

Scott, A.P. and Sumpter, J.P. 1983. A comparison of the female reproductive cycles of autumn-spawning and winterspawning strains of rainbow trout (Salmo gairdneri Richardson). Gen. Comp. Endocrinol. 52: 79-85.

Scott, A.P., Sheldrick, E.L. and Flint, A.P.F. 1982. Measurement of $17 \alpha, 20 \beta$-dihydroxy-4-pregnen-3-one in plasma of trout (Salmo gairdneri Richardson): Seasonal changes and response to salmon pituitary extract. Gen. Comp. Endocrinol. 46: 444-451.

Scott, A.P., Sumpter, J.P. and Hardiman, P.A. 1983. Hormone changes during ovulation in the rainbow trout ( $\mathrm{Sal}$ mo gairdneri Richardson). Gen. Comp. Endocrinol. 47: 128-134.

Sower, S.A. and Schreck, C.B. 1982. Steroid and thyroid hormones during sexual maturation of coho salmon (Oncorhynchus kisutch) in seawater or freshwater. Gen. Comp. Endocrinol. 47: 42-53.

Springate, J.R.C., Bromage, N.R., Elliott, J.A.K. and Hudson, D.L. 1984. The timing of ovulation and stripping and their effects on the rates of fertilization and eying, hatch and swimup in the rainbow trout (Salmo gairdneri). Aquaculture 43: 313-322.

Stuart-Kregor, P.A.C., Sumpter, J.P. and Dodd, J.M. 1981. The involvement of gonadotropin and sex steroids in the control of reproduction in the parr and adults of Atlantic salmon, Salmo salar L. J. Fish. Biol. 18: 59-72.

Tam, W.H. and Payson, P.D. 1986. Effects of chronic exposure 
to sublethal $\mathrm{pH}$ on growth, egg production, and ovulation in brook trout, Salvelinus fontinalis. Can. J. Fish. Aqu. Sci. 43: 275-280.

Tam, W.H., Roy, R.J.J. and Makaran, R. 1986. Ovarian cycle and plasma concentrations of estrogen and vitellogenin in brook trout (Salvelinus fontinalis, Mitchill). Can. J. Zool. 64: 744-751.

Theofan, G. and Goetz, F.W. 1983. The in vitro synthesis of final maturational steroids by ovaries of brook trout (Salvelinus fontinalis) and yellow perch (Perca flavescens). Gen. Comp. Endocrinol. 51: 84-95.

Truscott, B., Idler, D.R., So, Y.P. and Walsh, J.M. 1986. Maturational steroids and gonadotropins in upstream migratory sockeye salmon. Gen. Comp. Endocrinol. 62: 99-110.

Ueda, H., Hiroi, O., Hara, A., Yamauchi, K. and Nagahama, Y. 1984. Changes in serum concentrations of steroid hormones, thyroxine, and vitellogenin during spawning migration of chum salmon, Oncorhynchus keta. Gen. Comp. Endocrinol. 58: 203-211.

Van Der Kraak, G., Dye, H.M. and Donaldson, E.M. 1984. Ef- fects of LH-RH and Des-Gly 10(D-A 1G6]LH-R4-ethylamide on plasma sex steroid profiles in adult female coho salmon (Oncorhynchus kisutch). Gen. Comp. Endocrinol. 55: 36-45. Wright, R.S. and Hunt, S.M.V. 1982. A radioimmunoassay for $17 \alpha, 20 \beta$-dihydroxy-4-pregnen-3-one: Its use in measuring changes in serum levels at ovulation in Atlantic salmon (Salmo salar), coho salmon (Oncorhynchus kisutch), and rainbow trout (Salmo gairdneri). Gen. Comp. Endocrinol. 47: 475-482.

Yamauchi, K., Kagawa, H., Ban, M., Kasahara, N. and Nagahama, Y. 1984. Changes in plasma estradiol-17 $\beta$ and $17 \alpha$-20 $\beta$-dihydroxy-4-pregnen-3-one levels during final oocyte maturation of the masu salmon Oncorhynchus masou. Bull. Jap. Soc. Sci. Fish. 50, 2137.

Young, G., Crim, L.W., Kagawa, H., Kambegawa, A. and Nagahama, Y. 1983. Plasma 17 $\alpha, 20 \beta$-dihydroxy-4-pregnen-3-one levels during sexual maturation of amago salmon (Oncorhynchus rhodurus): correlation with plasma gonadotropin and in vitro production by ovarian follicles. Gen. Comp. Endocrinol. 51: 96-105. 